Research Article

\title{
Genetic Algorithm Based Optimal Placement of Tesc and Upfc in the Nigeria 330KV Integrated Transmission Line Network at Different Reactive Power Loadings
}

\author{
O. Eseosa* and U. Roland
}

Electrical/Electronic Engineering, Faculty of Engineering, University of Port Harcourt, Rivers State

Received 2 February 2012; Accepted 20 November 2013

\begin{abstract}
The Nigeria 330KV integrated power network consisting of 52 buses, 64 transmission lines and sixteen generating stations was studied. The network was subjected to different reactive power loadings ranging from $25 \%, 50 \%, 75 \%$, $100 \%, 125 \%$ and $150 \%$ respectively with and without UPFC and TCSC FACTS devices using Newton-Raphson power flow algorithm and Genetic Algorithm (GA) for optimally locating these devices on the network. The heavily loaded active power lines were identified. The heavily loaded active power lines are thirteen (13). These include: KatampeShiroro, Akangba-Ikejawest, Aiyede-Oshogbo, Alaoji-Onitsha, Egbin-ikejawest, Jebba-Oshogbo, Jebba-Shiroro, JosMakurdi, Kaduna-Shiroro, Kaduna-Kano, Ajaokuta-Benin, Benin-Ikejawest, and Benin-Onitsha. The ten(10) heavily loaded reactive power lines include: B-Kebbi-Kainji, Benin-Oshogbo, Benin-Egbin, Benin-Sapele, Damaturu-Gombe, Damaturu-Maiduguri, Gombe-Yola, Jalingo-Yola, Ikeja West-Oshogbo and Jos-New Haven. Weak buses were NewHaven $(0.9201 \mathrm{pu})$,Damaturu (0.9283pu), Gombe (0.9405pu), Maiduguri(0.9425pu), Makurdi (0.9260pu), Jalingo $(0.9354 \mathrm{pu})$,Erunkan(0.9314pu) and Jos (0.9461pu).Ten(10) heavily loaded reactive power lines include:B-Kebbi-Kainji, Benin-Oshogbo, Benin-Egbin, Benin-Sapele, Damaturu-Gombe, Damaturu-Maiduguri, Gombe-Yola, Jalingo-Yola, Ikeja West-Oshogbo and Jos-New Haven. Using GA for optimal location of these devices, eight (8) of the thirteen (13) lines were installed with UPFC. These are Akangba-Ikejawest, Alaoji-Onitsha, Jebba-Oshogbo, Jos-Makurdi, Kaduna-Kano, Ajaokuta-Benin, Benin-Ikeja west, and Benin-Onitsha. Also of the eight (8) weak buses six (6) had UPFC and the improved bus voltage values are Damaturu $(0.9983 \mathrm{pu})$, Gombe $(0.9751 \mathrm{pu})$, Maiduguri $(0.9815 \mathrm{pu})$, Makurdi $(0.9804$ $\mathrm{pu})$, Jalingo $(0.9541 \mathrm{pu})$ and Jos $(0.9646 \mathrm{pu})$. Six (6) TCSC devices were incorporated on the ten (10) heavily loaded lines, which include Ikeja West-Oshogbo, Damaturu-Maiduguri, Gombe-Yola, Jos-New Haven, Benin-Oshogbo and BKebbi-Kainji. Comparison was made between the power losses with and without FACTS devices at the various percentage loadings. Real and active power losses.
\end{abstract}

Keywords: Antenna array, particle swarm optimization, phased array.

\section{Introduction}

Flexible Alternating Current Transmission Systems (FACTS) Devices use power electronic technology for effective control of electrical quantities, such as active and reactive power, phase angles and bus voltages, line impedances and terminal voltages, for the overall improvement of power quality in the network. The use of these devices allows for effective utilization of power system network at the generation, transmission and

\footnotetext{
*E-mail address: 00morogiuwa@yahoo.com
}

ISSN: 1791-2377 (C) 2013 Kavala Institute of Technology. All rights reserved. distribution stations and ensures power systems stability even when the network is subjected to excess active and reactive loadings(1). Assessment of the impact of FACTS Devices on power system network were studied in $(2,3,4$ and 5), to increase power transfer over transmission lines. The optimal location and placement of these devices in power system network using genetic algorithm for optimization and increased system loadings were studied in $(6,7,8,9$ and 13$)$.

The aim of this work is to optimally locate FACTS (Unified Power Flow Controllers (UPFC) and the Thyristor Controlled Series Controllers (TCSC) devices in the Nigeria 
$330 \mathrm{KV}$ integrated power network for power transfer increase and loss minimization, when subjected to different active and reactive power loadings.

Currently, the control and regulation of line flows (active and reactive power), line impedance, bus voltages and phase angles in the Nigeria power network when subjected to different percentage levels of power loadings (active and reactive) is done by controlling/regulating the reactive power from the generators, addition/removal of series and shunt reactors and controlling the positions of the tap changing transformers. With the existing control mechanism, the total active and reactive power loss is $92.633 \mathrm{MW}+85.9432 \mathrm{MVar}$, of which $39 \%$ of the total reactive power losses is from the generating stations (1).Thus, FACTS devices is used for the control and regulation of these parameters. This work uses UPFC to improve the weak buses, phase angles and relief the heavily loaded active power lines, while the TCSC is used to relief the heavily loaded reactive power lines and to alter their line impedances. Genetic algorithm (GA) based technique is used for optimal placement of these devices.

\section{Fact Device Models for the Study}

Different algorithms for the various FACT devices used for the study are TCSC and UPFC. These were formulated using the relevant equations and incorporated in the Newton Raphson (N-R) method for the power flow study and also an evolutionary algorithm (Genetic algorithm) for optimal placement was employed. N-R based Power flow is carried out at different percentage line loadings $(25 \%, 50 \%, 75 \%, 100 \%, 125 \%$ and $150 \%)$ of active and reactive power, to determine the steady - state operating conditions of $330 \mathrm{KV}$ integrated power network, flow of active and reactive power, voltage magnitudes and phase angles in all buses without the FACTS devices. Then a proposed model, where these devices are incorporated optimally was also carried out. Comparisons were made with and without FACTS devices on the integrated power network in terms of transmission line losses, bus voltages and loading capacities.

\subsection{TCSC}

It is used to control effectively the $330 \mathrm{KV}$ transmission line parameters by connecting a variable reactance in series with the transmission line. This increases the transmission line capability which in turn reduces the transmission lines net impedance. The TCSC perform the function of a variable reactance compensator, either in the capacitive or inductive mode by either adding/removing an inductive or capacitive component to the main transmission line reactance. Operating in the inductive region increase the length of the line thereby reducing the lines ability to transfer power. In the capacitive mode, the line length is shortened, thus increasing power transfer margins. Adjusting the phase angle difference across a series connected impedance also control the active power flow.

\subsubsection{Power Flow Model of TCSC}

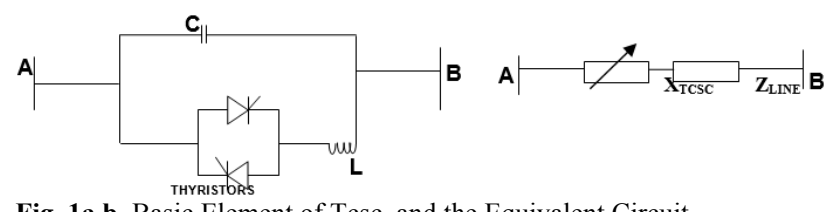

Fig. 1a,b. Basic Element of Tcsc, and the Equivalent Circuit
This is expressed mathematically as:

$X_{\text {reactance }}=X_{\text {Line }}+X_{T C S C}$

where:

$X_{T C S C}=r_{T C S C} * X_{\text {Line }}$

$r_{T C S C}$ is the degree of compensation as provided by the TCSC. Its working range is between $-0.7 \mathrm{xl}_{\text {ine }}$ to $0.2 \mathrm{x}_{\text {line }}(14$,

$15)$. its range of values depends on the reactance of the line where it is placed.

\subsection{UPFC.}

It allows the simultaneous control of active and reactive power flow and voltage magnitude at the series- shunt compensator terminals. The active power control takes place between the series converter and the AC system, while the shunt converter generates or absorbs reactive power so as to provide voltage magnitude at the point of connection of the device and the AC system.

\subsubsection{Power Flow Model of UPFC.}

It controls the power flow in the transmission systems by controlling the impedance, phase angles and voltage magnitude. The basic structure of UPFC consist of two voltage source converters $\left(\mathrm{V}_{\mathrm{SC} 1}\right.$ and $\left.\mathrm{V}_{\mathrm{SC} 2}\right)$ : one connected in parallel and the other in series to the line with these two converters. UPFC supplies both reactive and active power through the converters. Figure 2 shows the basic element of a UPFC.

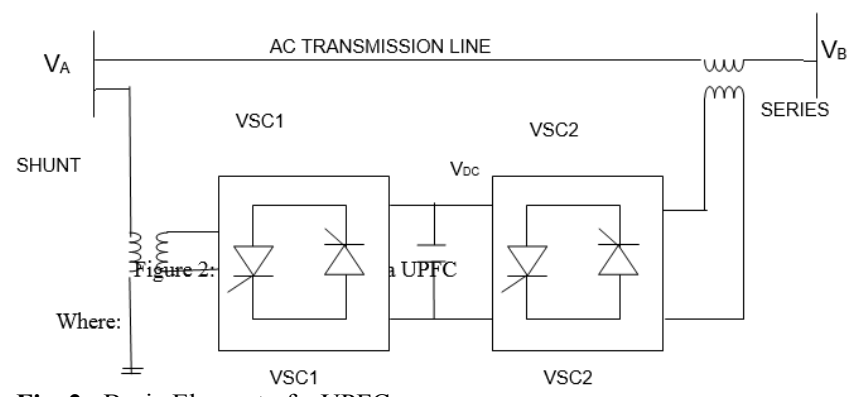

Fig. 2. Basic Element of a UPFC

where:

$\mathrm{V}_{\mathrm{SC} 1}$ and $\mathrm{V}_{\mathrm{SC} 2}=$ Shunt and series connected controllers through shunt and series transformers.

$\mathrm{V}_{\mathrm{DC}}=$ phase voltage angle

$\mathrm{V}_{\mathrm{A}}$ and $\mathrm{V}_{\mathrm{B}}=$ Bus voltages at node $\mathrm{A}$ and $\mathrm{B}, \mathrm{n}$ is total number of nodes.

It is used to control line impedance, terminal voltages and phase voltages and the power flow through the transmission line A-B is given as

$P_{A}=\frac{\mathrm{v}_{\mathrm{A}} \mathrm{V}_{\mathrm{B}}}{\mathrm{XAB} \mid}\left(\cos \left(\delta_{A}-\delta_{B}\right)\right)$

$\mathrm{V}_{\mathrm{A}}, \mathrm{V}_{\mathrm{B}}$ are bus voltages. $\mathrm{X}_{\mathrm{AB}}, \delta_{A}$ and $\delta_{B}$ are transmission line impedance and phase voltages between buses $\mathrm{A}$ and $\mathrm{B}$ $\mathrm{P}_{\mathrm{A}}, \mathrm{P}_{\mathrm{B}}, \mathrm{Q}_{\mathrm{A}}$ and $\mathrm{Q}_{\mathrm{B}}$ are the active and reactive power at node $\mathrm{A}$ and $\mathrm{B}$ respectively.

$$
\begin{aligned}
& P_{A}-P_{B}= \\
& \sum_{B=A}^{n}\left\|V_{A} V_{B}\right\|\left(G_{A B}\left(\cos \left(\delta_{A B}\right)\right)+B_{A B}\left(\cos \left(\delta_{A B}\right)\right)\right. \\
& Q_{A}-Q_{B}=\sum_{B=A}^{n}\left\|V_{A} V_{B}\right\|\left(G_{A B}\left(\sin \left(\delta_{A B}\right)\right)+B_{A B}\left(\cos \left(\delta_{A B}\right)\right)\right.
\end{aligned}
$$




$$
P_{A}-P_{B}=\sum_{B=A}^{n}\left\|V_{A} V_{B}\right\|\left(G_{A B}\left(\cos \left(\delta_{A B}\right)\right)+B_{A B}\left(\sin \left(\delta_{A B}\right)\right)+\right.
$$$$
\triangle P
$$
$\Delta Q$

$$
Q_{A}-Q_{B}=\sum_{B=A}^{n}\left\|V_{A} V_{B}\right\|\left(G_{A B}\left(\sin \left(\delta_{A B}\right)\right)+B_{A B}\left(\cos \left(\delta_{A B}\right)\right)+\right.
$$

On incorporation of UPFC at bus B gives

$$
\begin{aligned}
& P_{U P F C}-P_{B}=\sum_{B=A}^{n}\left\|V_{U P F C} V_{B}\right\|\left(G_{(U P F C)(B)}\left(\cos \left(\delta_{A B}\right)\right)+\right. \\
& B_{A B}\left(\cos \left(\delta_{A B}\right)\right) \\
& \quad \quad Q_{A}-Q_{B}= \\
& \sum_{B=A}^{n}\left\|V_{A} V_{B}\right\|\left(G_{A B}\left(\sin \left(\delta_{A B}\right)\right)+B_{A B}\left(\cos \left(\delta_{A B}\right)\right)\right.
\end{aligned}
$$

\section{Nigeria 330KV Integrated Power System}

Nigeria is gradually becoming industrialized and requires large amount of power to meet the high demand of consumers, thus making the network more congested. In an attempt to solve this, the Federal Government embarked on improving the power industry by building more generating stations, transmission and distribution stations/lines. Prior to the $330 \mathrm{KV}$ integrated power system, the existing network consist of nine (9) generating stations, twenty eight (28) buses and thirty two (32) transmission lines. The integrated power network under study consists of fifty two (52) buses, sixty four (64) transmission lines and sixteen (16) generating stations. One line diagram of the network is shown in appendix A.

With the existing power generating stations, National Integrated Power Producers (NIPP) and the Independent Power Producers (IPP), the present installed capacity is $8,692.25 \mathrm{MW}$, with average available capacity and availability factor of $4,850.77 \mathrm{MW}$ and 0.597 respectively. Summary of this is shown in Table 1.0. While table 2.0 shows the bus voltages and numbers used for the study.

Table 1. The availability factor, average availability and installed capacity of present generating stations

\begin{tabular}{l|l|c|c|c}
\hline S/N & Power Station & $\begin{array}{c}\text { Availability } \\
\text { Factor }\end{array}$ & $\begin{array}{c}\text { Average } \\
\text { Availability } \\
\text { (MW) }\end{array}$ & $\begin{array}{c}\text { Installed } \\
\text { Capacity(MW) }\end{array}$ \\
\hline 1 & KAINJI & 0.586 & 445.45 & 760 \\
2 & JEBBA HYDRO & 0.792 & 457.99 & 578.40 \\
3 & SHIRORO & 0.674 & 404.56 & 600.00 \\
4 & EGBIN STEAM & 0.743 & 980.89 & 1320.00 \\
5 & TRANS-AMADI & 0.256 & 25.60 & 100 \\
6 & A.E.S & 0.783 & 236.44 & 302.00 \\
7 & SAPELE & 0.195 & 199.07 & 1020.00 \\
8 & OKPAI GAS & 0.929 & 446.25 & 480.00 \\
9 & AFAM (I-V) & 0.068 & 63.52 & 931.60 \\
10 & AFAM VI & 0.649 & 322.82 & 497.25 \\
11 & DELTA GAS & 0.289 & 255.33 & 882.00 \\
12 & GEREGU GAS & 0.725 & 300.00 & 414.00 \\
13 & OMOKU GAS & 0.961 & 96.05 & 100.00 \\
14 & OMOTOSHO & 0.890 & 298.15 & 335.00 \\
15 & IBOM & 0.078 & 2.90 & 37.00 \\
16 & OLORUNSHOGO & 0.943 & 315.75 & 335.00 \\
& PHASE 1 AND 2 & & & \\
& & 0.597 & $4,850.77 \mathrm{MW}$ & $8,692.25 \mathrm{MW}$ \\
\hline
\end{tabular}

Where

availability factor $=\frac{\text { Average Availability }(\mathrm{MW})}{\text { Installed Capacity }(\mathrm{MW})}$

Average availability factor $=\frac{\text { Availability Factor }}{\text { No of Generating Stations }}$
Table 2. Bus Voltages in the Integrated Power System

\begin{tabular}{l|l|l|l|l|l}
\hline S/NO & BUSES & S/NO & BUSES & S/NO & BUSES \\
\hline 1 & Shiroro & 21 & New Haven & 41 & Yola \\
& & & South & & \\
2 & Afam & 22 & Makurdi & 42 & Gwagwalada \\
3 & Ikot-Ekpene & 23 & B-kebbi & 43 & Sakete \\
4 & Port- & 24 & Kainji & 44 & Ikot-Abasi \\
& Harcourt & & & & \\
5 & Aiyede & 25 & Oshogbo & 45 & Jalingo \\
6 & Ikeja west & 26 & Onitsha & 46 & Kaduna \\
7 & Papalanto & 27 & Benin North & 47 & Jebba GS \\
8 & Aja & 28 & Omotosho & 48 & Kano \\
9 & Egbin PS & 29 & Eyaen & 49 & Katampe \\
10 & Ajaokuta & 30 & Calabar & 50 & Okpai \\
11 & Benin & 31 & Alagbon & 51 & Jebba \\
12 & Geregu & 32 & Damaturu & 52 & AES \\
13 & Lokoja & 33 & Gombe & & \\
14 & Akangba & 34 & Maiduguri & & \\
15 & Sapele & 35 & Egbema & & \\
16 & Aladja & 36 & Omoku & & \\
17 & Delta PS & 37 & Owerri & & \\
18 & Alaoji & 38 & Erunkan & & \\
19 & Aliade & 39 & Ganmo & & \\
20 & New Haven & 40 & Jos &
\end{tabular}

Even the Nigeria $330 \mathrm{KV}$ integrated power system is still characterised with high power congestion (1). However, incorporation of FACTS controllers in their appropriate location in the network will be investigated. The heavily loaded lines with high active power flow and weak bus voltages magnitudes and phase angles will be controlled by UPFC. Heavily loaded lines with high reactive power flow are controlled by the TCSC.

\section{Genetic Algorithms (GA)}

It is one of the evolutionary Algorithms search technique based on mechanism of natural selection and genetics. It searches several possible solutions simultaneously and do not require prior knowledge or special properties of the objective function $(16,17)$. GA starts with initial random generation of population of binary string, calculates fitness values from the initial population, after which the selection, cross over and mutation are done until the best population is obtained. The flow chart for the GA optimization is shown in appendix B.

\subsection{Initial Population/Selection}

It is obtained from the parameters below

$$
\begin{aligned}
& \mathrm{N}_{1} \text { : Number of FACT devices to be located } \\
& \mathrm{N}_{2} \text { : Type of FACT devices } \\
& \mathrm{N}_{3} \text { : The possible location of FACT devices } \\
& \mathrm{N}_{4} \text { : Number of individuals of the population. (11) }
\end{aligned}
$$

It generates and selects the initial population of the binary strings from all po ssible locations. If there is need for FACTS devices to be located, then from the binary string a first value of one will be selected. If it is not necessary for the device to be located, the next value of zero will be selected. Initial population is generated on the basis of population size and string length. The type of FACT devices are also selected after its location is established.

\subsection{Encoding and Initialization of the Device}


The initialization of TCSC reactance values ranging between $-0.7 \mathrm{X}_{\mathrm{L}}-0.2 \mathrm{X}_{\mathrm{L}}$ is randomly generated. Random numbers sets consisting of 0 's and 1 's are generated. For transmission lines having the TCSC, a value of 1 is given for a device that will exist on the line and a value of 0 is given a line that it will not exist. To obtain the rating of the TCSC, the values generated between $\left(-0.7 \mathrm{X}_{\mathrm{L}}\right)-\left(+0.2 \mathrm{X}_{\mathrm{L}}\right)$ is multiplied with the generated random numbers.

\section{For UPFC}

A set of random numbers is generated. If there is a UPFC device necessary for the transmission line, a 1 is generated, and a 0 means there is no device necessary.

\subsection{Fitness Computation of Each Device}

Fitness computation evaluates each individual population and then compares different solutions. This applies to the two FACTS devices.

\section{Reproduction}

Though various methods are used in selecting the fittest individual in the reproduction process. These include: Rank, Tournament, Boltzmann and Roulette-Wheel selection. In this work, the Roulette-wheel selection is utilized. Random numbers are generated in the interval whose segment spans this selection.

\section{Cross Over}

Cross over produces new strings by the exchange of information among the strings of mating pools. Probability of cross over rate varies from 0 to 1 and range from $(0.7)$ $(+1)$ for population within the range of 50-300. (1)

\section{Mutation}

Mutation introduces some sort of artificial diversification in the population to avoid premature convergence to local optimum $(11,16)$.

Table 3. showed the various parameters used for the study using GA for optimal location of UPFC and TCSC devices.

Table 3. Parameters Used For the Genetic Algorithm for All the Various FACTS Devices

\begin{tabular}{l|c}
\hline Parameter & Value/Type \\
\hline Maximum Generations & 200 \\
Population Size & 50 \\
Type Of Cross Over & Arithmetic \\
Type Of Mutation & Non-Uniform \\
Termination Method & Maximum Generation \\
Reproduction/Selection Method & Roulette Wheel \\
\hline
\end{tabular}

\section{Results}

The Nigeria $330 \mathrm{KV}$ integrated network consisting of 52 buses, 64 transmission lines and sixteen (16) generating stations, were subjected to different levels of reactive loadings ranging from $25 \%, 50 \%, 75 \%, 100 \%, 125 \%$ and $150 \%$ without and with FACTS (STATCOM,UPFC and
TCSC) devices respectively. GA based optimization technique was used to optimally place UPFC and TCSC on the transmission lines.

\subsection{Without Facts Devices in the Nigeria $330 \mathrm{kv}$ Integrated Network}

A power flow study was carried out using N-R algorithm, at different percentage of reactive loadings, to obtain the active and reactive power flows on the lines, phase angles and bus voltages. Table $4.0 \mathrm{a}$ showed the result obtained at different active and reactive power loadings. Table $4.0 \mathrm{~b}$ showed the bus voltages and phase angles of the weak buses.

\subsection{With Facts Devices in the Nigeria 330kv Integrated Power Network}

The next step involved incorporating FACTS devices (UPFC and TCSC) into the N-R algorithm to obtain the values of active and reactive power flows at different loadings of $25 \%, 50 \%, 75 \%, 100 \% 125 \%$ and $150 \%$, using GA for optimal placement of FACTS devices in the network. UPFC regulates both bus voltage magnitudes and phase angles while TCSC modifies the transmission line reactance to allow for regulation of reactive power flow either in the capacitive or inductive mode. The heavily loaded active power lines are thirteen (13). These include: Katampe-Shiroro(49-1), Akangba-Ikejawest(14-6), AiyedeOshogbo(5-25), Alaoji-Onitsha(18-26), Egbin-ikeja West(96), Jebba-Oshogbo(51-25), Jebba-Shiroro(51-1), JosMakurdi,(40-22), Kaduna-Shiroro(46-1), Kaduna-Kano(4648), Ajaokuta-Benin(10-11), Benin-Ikeja West(11-6), and Benin-Onitsha(11-26). However, using GA for optimal location of these devices, eight (8) of the thirteen (13) lines were installed with UPFC. These include: AkangbaIkejawest (14-6), Alaoji-Onitsha(18-26), Jebba-Oshogbo(5125), Jos-Makurdi (40-22), Kaduna-Kano (46-48), AjaokutaBenin (10-11), Benin-Ikeja west (11-6), and Benin-Onitsha (11-26). Also of the eight weak buses in the network as shown in table 4.0b, six (6) had UPFC. These include Damaturu (32), Gombe (33), Maiduguri (34), Makurdi (22), Jalingo (45) and Jos (40). The ten(10) heavily loaded reactive power lines include: B-Kebbi-Kainji(23-24), BeninOshogbo(11-25), Benin-Egbin(11-9), Benin-Sapele(11-15), Damaturu-Gombe(32-33), Damaturu-Maiduguri(32-34), Gombe-Yola(33-41), Jalingo-Yola(45-41), Ikeja WestOshogbo(6-25) and Jos-New Haven(40-22).GA optimally located six(6) TCSC devices on the ten(10) heavily loaded lines. These include Ikeja West-Oshogbo(6-25), DamaturuMaiduguri(32-34), Gombe-Yola(33-41), Jos-New Haven(4022), Benin-Oshogbo(11-25) and B-Kebbi-Kainji(23-24).The required number of UPFC is fourteen (14) and TCSC is six (6).Hence the total FACTS device become twenty (20) as specified by GA. This implies that the parameters that will make up the population size for the GA is minimum of forty (40). Each UPFC controls two parameters (bus voltages and phase angles) while the TCSC modifies the transmission line reactance. Table 5.0a showed the result obtained at different active and reactive power loadings while Table $5.0 \mathrm{~b}$ showed the bus voltages and phase angles. 
Table 4.A. Active and Reactive Power Flows at Different Loadings without Facts Devices

\begin{tabular}{|c|c|c|c|c|c|c|c|c|c|c|c|c|c|}
\hline \multicolumn{2}{|c|}{$\begin{array}{l}\text { CONNECTED } \\
\text { BUS }\end{array}$} & \multicolumn{2}{|c|}{$\begin{array}{l}\text { Active and Reactive } \\
\text { power Flow for } \\
\text { 25\% Loading in Per } \\
\text { Unit (PU) }\end{array}$} & \multicolumn{2}{|c|}{$\begin{array}{l}\text { Active and Reactive } \\
\text { Power Flow for } \\
\text { 50\% Loading in Per } \\
\text { Unit (PU) }\end{array}$} & \multicolumn{2}{|c|}{$\begin{array}{l}\text { Active and Reactive } \\
\text { Power Flow for } \\
\text { 75\% Loading in Per } \\
\text { Unit (PU) }\end{array}$} & \multicolumn{2}{|c|}{$\begin{array}{l}\text { Active and Reactive } \\
\text { power Flow for } \\
100 \% \text { Loading in } \\
\text { Per Unit (PU) }\end{array}$} & \multicolumn{2}{|c|}{$\begin{array}{l}\text { Active and Reactive } \\
\text { Power Flow for } \\
125 \% \text { Loading in } \\
\text { Per Unit (PU) }\end{array}$} & \multicolumn{2}{|c|}{$\begin{array}{l}\text { Active and Reactive } \\
\text { Power Flow for } \\
150 \% \text { Loading in } \\
\text { Per Unit (PU) }\end{array}$} \\
\hline From & To & $P$ & $\mathbf{Q}$ & $\mathbf{P}$ & $\mathbf{Q}$ & $\mathbf{P}$ & $\mathbf{Q}$ & $\mathbf{P}$ & $\mathbf{Q}$ & $P$ & $\mathbf{Q}$ & $P$ & $\mathbf{Q}$ \\
\hline 49 & 1 & 0.1775 & 0.0727 & 0.1771 & 0.0723 & 0.1776 & 0.0718 & 0.1772 & 0.0712 & 0.1769 & 0.0706 & 0.1767 & 0.0702 \\
\hline 14 & 6 & 0.0199 & 0.0120 & 0.0195 & 0.0118 & 0.0120 & 0.0113 & 0.0190 & 0.0110 & 0.0191 & 0.0117 & 0.0199 & 0.0112 \\
\hline 2 & 18 & 0.0556 & 0.0383 & 0.0551 & 0.0379 & 0.0550 & 0.0372 & 0.0548 & 0.0368 & 0.0550 & 0.0364 & 0.0549 & 0.0361 \\
\hline 2 & 3 & -0.0038 & 0.0017 & -0.0034 & 0.0015 & -0.0041 & 0.0012 & -0.0039 & 0.0010 & -0.0041 & 0.0008 & -0.0039 & 0.0077 \\
\hline 2 & 4 & 0.0063 & 0.0023 & 0.0059 & 0.0020 & 0.0059 & 0.0016 & 0.0061 & 0.0013 & 0.0056 & 0.0010 & 0.0058 & 0.0009 \\
\hline 16 & 17 & -0.0512 & 0.0566 & -0.0509 & 0.0569 & -0.0514 & 0.0562 & -0.0511 & 0.0559 & -0.0509 & 0.0550 & -0.0511 & 0.0546 \\
\hline 5 & 25 & 0.1621 & 0.2790 & 0.1617 & 0.3000 & 0.1622 & 0.2600 & 0.1619 & 0.2880 & 0.1622 & 0.2872 & 0.1619 & 0.2590 \\
\hline 5 & 6 & 0.0186 & 0.0119 & 0.0182 & 0.0123 & 0.0184 & 0.0119 & 0.0180 & 0.0116 & 0.0182 & 0.0111 & 0.0180 & 0.0108 \\
\hline 5 & 7 & 0.0283 & 0.0182 & 0.0279 & 0.0186 & 0.0273 & 0.0182 & 0.0270 & 0.0179 & 0.0272 & 0.0173 & 0.0269 & 0.0169 \\
\hline 8 & 9 & 0.0999 & 0.0619 & 0.0996 & 0.0623 & 0.0998 & 0.0619 & 0.0995 & 0.0616 & 0.0997 & 0.0612 & 0.0995 & 0.0608 \\
\hline 8 & 31 & 0.0187 & 0.0119 & 0.0184 & 0.0121 & 0.0192 & 0.0119 & 0.0189 & 0.0116 & 0.0192 & 0.0113 & 0.0195 & 0.0109 \\
\hline 10 & 11 & 0.2150 & 0.0134 & 0.2114 & 0.0136 & 0.2180 & 0.0132 & 0.2158 & 0.0129 & 0.2178 & 0.0124 & 0.2192 & 0.0120 \\
\hline 10 & 12 & 0.0239 & 0.0166 & 0.0236 & 0.0162 & 0.0241 & 0.0158 & 0.0239 & 0.0154 & 0.0241 & 0.0150 & 0.0239 & 0.0148 \\
\hline 10 & 13 & 0.0289 & 0.0180 & 0.0286 & 0.0184 & 0.0291 & 0.0180 & 0.0289 & 0.0177 & 0.0286 & 0.0172 & 0.0288 & 0.0169 \\
\hline 16 & 15 & 0.1315 & 0.0163 & 0.1311 & 0.0161 & 0.1317 & 0.0157 & 0.1319 & 0.0154 & 0.1317 & 0.0151 & 0.1317 & 0.0148 \\
\hline 18 & 26 & 0.2461 & 0.1781 & 0.2458 & 0.1778 & 0.2463 & 0.1772 & 0.2460 & 0.1769 & 0.2462 & 0.1765 & 0.2458 & 0.1761 \\
\hline 18 & 3 & 0.0457 & 0.0294 & 0.0454 & 0.0291 & 0.0462 & 0.0289 & 0.0459 & 0.0285 & 0.0459 & 0.0281 & 0.0457 & 0.0278 \\
\hline 18 & 37 & 0.0155 & 0.0116 & 0.0152 & 0.0114 & 0.0152 & 0.0110 & 0.0149 & 0.0108 & 0.0147 & 0.0103 & 0.0145 & 0.0101 \\
\hline 19 & 21 & -0.0026 & 0.0050 & -0.0023 & 0.0047 & -0.0031 & 0.0042 & -0.0029 & 0.0039 & -0.0031 & 0.0034 & -0.0033 & 0.0030 \\
\hline 19 & 22 & 0.0031 & -0.0024 & 0.0026 & -0.0020 & 0.0032 & -0.0018 & 0.0033 & -0.0014 & 0.0030 & -0.0011 & 0.0028 & -0.0008 \\
\hline 23 & 24 & 0.0885 & 0.0543 & 0.0882 & 0.0540 & 0.0887 & 0.0538 & 0.0884 & 0.0533 & 0.0889 & 0.0529 & 0.0887 & 0.0524 \\
\hline 11 & 6 & 0.1592 & -0.0114 & 0.1565 & -0.0110 & 0.1620 & -0.0108 & 0.1601 & -0.0105 & 0.1587 & -0.0101 & 0.1562 & -0.0980 \\
\hline 11 & 15 & 0.0257 & 0.0595 & 0.0253 & 0.0591 & 0.0259 & 0.0588 & 0.0260 & 0.0584 & 0.0258 & 0.0581 & 0.0256 & 0.0577 \\
\hline 11 & 17 & 0.0611 & -0.0549 & 0.0608 & -0.0546 & 0.0615 & -0.0541 & 0.0613 & -0.0539 & 0.0610 & -0.0533 & 0.0608 & -0.0530 \\
\hline 11 & 25 & 0.0108 & 0.0843 & 0.0105 & 0.0840 & 0.0110 & 0.0836 & 0.0108 & 0.0833 & 0.0111 & 0.0828 & 0.0108 & 0.0823 \\
\hline 11 & 26 & 0.2510 & -0.0194 & 0.2490 & -0.0190 & 0.2513 & -0.0187 & 0.2519 & -0.0184 & 0.2521 & -0.0181 & 0.2523 & -0.0178 \\
\hline 11 & 27 & 0.0393 & 0.0294 & 0.0390 & 0.0290 & 0.0398 & 0.0286 & 0.0401 & 0.0283 & 0.0402 & 0.0279 & 0.0398 & 0.0274 \\
\hline 11 & 9 & 0.0921 & 0.0779 & 0.0918 & 0.0774 & 0.0924 & 0.0771 & 0.0921 & 0.0768 & 0.0923 & 0.0762 & 0.0920 & 0.0759 \\
\hline 11 & 28 & 0.0476 & -0.0343 & 0.0473 & -0.0341 & 0.0479 & -0.0348 & 0.0477 & -0.0344 & 0.0475 & -0.0341 & 0.0472 & -0.0338 \\
\hline 27 & 29 & -0.0308 & 0.0192 & -0.0305 & 0.0197 & -0.0311 & 0.0194 & -0.0308 & 0.0192 & -0.0310 & 0.0188 & -0.0307 & 0.0184 \\
\hline 30 & 3 & 0.0283 & 0.0182 & 0.0284 & 0.0179 & 0.0289 & 0.0174 & 0.0285 & 0.0172 & 0.0283 & 0.0169 & 0.0279 & 0.0164 \\
\hline 32 & 33 & 0.0367 & -0.0940 & 0.0364 & -0.0938 & 0.0369 & -0.0935 & 0.0365 & -0.0937 & 0.0367 & -0.0939 & 0.0367 & -0.0942 \\
\hline 32 & 34 & 0.0485 & -0.0843 & 0.0482 & -0.0846 & 0.0490 & -0.0841 & 0.0487 & -0.0844 & 0.0489 & -0.0846 & 0.0486 & -0.0841 \\
\hline 35 & 37 & -0.0181 & 0.0132 & -0.0179 & 0.0136 & -0.0182 & 0.0132 & -0.0179 & 0.0130 & -0.0181 & 0.0124 & -0.0181 & 0.0121 \\
\hline 35 & 36 & -0.0112 & 0.0088 & -0.0109 & 0.0092 & -0.0114 & 0.0089 & -0.0112 & 0.0087 & -0.0110 & 0.0084 & -0.0108 & 0.0081 \\
\hline 9 & 6 & 0.2148 & 0.1549 & 0.2145 & 0.1544 & 0.2150 & 0.1540 & 0.2149 & 0.1538 & 0.2151 & 0.1533 & 0.2153 & 0.1530 \\
\hline 9 & 38 & -0.2605 & 0.0159 & -0.2602 & 0.0161 & -0.2609 & 0.0165 & -0.2605 & 0.0163 & -0.2602 & 0.0162 & -0.2599 & 0.0167 \\
\hline 38 & 6 & -0.2601 & 0.0158 & -0.2598 & 0.0159 & -0.2598 & 0.0156 & -0.2595 & 0.0158 & -0.2593 & 0.0157 & -0.2590 & 0.0160 \\
\hline 39 & 25 & 0.0266 & 0.0406 & 0.0267 & 0.0405 & 0.0269 & 0.0408 & 0.0264 & 0.0406 & 0.0270 & 0.0409 & 0.0268 & 0.0411 \\
\hline 39 & 51 & 0.0267 & -0.0305 & 0.0263 & -0.0304 & 0.0269 & -0.0306 & 0.0272 & -0.0308 & 0.0263 & -0.0309 & 0.0266 & -0.0312 \\
\hline 33 & 40 & 0.0674 & -0.1201 & 0.0676 & -0.1203 & 0.0681 & -0.1201 & 0.0676 & -0.1198 & 0.0678 & -0.1193 & 0.0676 & -0.1189 \\
\hline 33 & 41 & 0.0790 & -0.1002 & 0.0787 & -0.1003 & 0.0792 & -0.1000 & 0.0791 & -0.0980 & 0.0793 & -0.0977 & 0.0791 & -0.0972 \\
\hline 42 & 49 & 0.0115 & -0.0072 & 0.0117 & -0.0074 & 0.0120 & -0.0070 & 0.0122 & -0.0069 & 0.0120 & -0.0063 & 0.0119 & -0.0060 \\
\hline 42 & 13 & 0.0292 & -0.0181 & 0.0289 & -0.0185 & 0.0297 & -0.0182 & 0.0294 & -0.0179 & 0.0296 & -0.0174 & 0.0294 & -0.0170 \\
\hline 42 & 1 & 0.0175 & 0.0109 & 0.0173 & 0.0112 & 0.0180 & 0.0109 & 0.0178 & 0.0106 & 0.0182 & 0.0104 & 0.0179 & 0.0101 \\
\hline 6 & 25 & 0.0180 & -0.0247 & 0.0182 & -0.0251 & 0.0184 & -0.0247 & 0.0181 & -0.0244 & 0.0179 & -0.0241 & 0.0181 & -0.0238 \\
\hline 6 & 28 & 0.0474 & -0.0340 & 0.0471 & -0.0345 & 0.0477 & -0.0340 & 0.0478 & -0.0337 & 0.0482 & -0.0333 & 0.0483 & -0.0331 \\
\hline 6 & 7 & 0.0283 & 0.0185 & 0.0280 & 0.0182 & 0.0284 & 0.0179 & 0.0281 & 0.0175 & 0.0279 & 0.0171 & 0.0277 & 0.0169 \\
\hline 6 & 43 & 0.0364 & -0.0202 & 0.0361 & -0.0197 & 0.0368 & -0.0194 & 0.0369 & -0.0191 & 0.0367 & -0.0187 & 0.0364 & -0.0183 \\
\hline 44 & 3 & 0.0464 & 0.0332 & 0.0461 & 0.0329 & 0.0466 & 0.0325 & 0.0468 & 0.0322 & 0.0471 & 0.0318 & 0.0468 & 0.0313 \\
\hline 3 & 21 & 0.0496 & 0.0316 & 0.0493 & 0.0310 & 0.0499 & 0.0306 & 0.0494 & 0.0302 & 0.0496 & 0.0299 & 0.0494 & 0.0289 \\
\hline 45 & 41 & 0.0879 & -0.1138 & 0.0876 & -0.1142 & 0.0882 & -0.1139 & 0.0879 & -0.1136 & 0.0882 & -0.1132 & 0.0880 & -0.1129 \\
\hline 51 & 25 & 0.2638 & 0.3355 & 0.2634 & 0.3352 & 0.2640 & 0.3348 & 0.2638 & 0.3344 & 0.2639 & 0.3341 & 0.2637 & 0.3338 \\
\hline 47 & 51 & 0.1669 & 0.0606 & 0.1666 & 0.0606 & 0.1670 & 0.0605 & 0.1668 & 0.0605 & 0.1671 & 0.0608 & 0.1668 & 0.0607 \\
\hline 51 & 24 & -0.4846 & 0.0717 & -0.4843 & 0.0713 & -0.4849 & 0.0710 & -0.4851 & 0.0708 & -0.4849 & 0.0703 & -0.4847 & 0.0699 \\
\hline 51 & 1 & 0.1733 & 0.2580 & 0.1737 & 0.2576 & 0.1741 & 0.2572 & 0.1739 & 0.2569 & 0.1737 & 0.2565 & 0.1739 & 0.2561 \\
\hline 40 & 46 & 0.0029 & 0.0054 & 0.0026 & 0.0058 & 0.0031 & 0.0054 & 0.0029 & 0.0052 & 0.0027 & 0.0049 & 0.0029 & 0.0044 \\
\hline 40 & 22 & 0.1270 & -0.1005 & 0.1271 & -0.1006 & 0.1274 & -0.1007 & 0.1271 & -0.1006 & 0.1273 & -0.1004 & 0.1274 & -0.1006 \\
\hline 46 & 1 & 0.1509 & -0.1180 & 0.1506 & -0.1184 & 0.1512 & -0.1181 & 0.1509 & -0.1178 & 0.1512 & -0.1175 & 0.1514 & -0.1171 \\
\hline 46 & 48 & 0.1252 & -0.0886 & 0.1253 & -0.0890 & 0.1257 & -0.0888 & 0.1253 & -0.0885 & 0.1250 & -0.0882 & 0.1248 & -0.0879 \\
\hline 20 & 26 & 0.1346 & 0.0855 & 0.1343 & 0.0860 & 0.1350 & 0.0857 & 0.1348 & 0.0854 & 0.1351 & 0.0852 & 0.1349 & 0.0849 \\
\hline 20 & 21 & -0.0468 & 0.0260 & -0.0464 & 0.0263 & -0.0470 & 0.0261 & -0.0471 & 0.0259 & -0.0473 & 0.0254 & -0.0470 & 0.0251 \\
\hline 50 & 26 & 0.0429 & 0.0682 & 0.0426 & 0.0778 & 0.0421 & 0.0775 & 0.0429 & 0.0772 & 0.0422 & 0.0768 & 0.0420 & 0.0764 \\
\hline 26 & 37 & 0.0156 & 0.0120 & 0.0152 & 0.0116 & 0.0156 & 0.0112 & 0.0153 & 0.0110 & 0.0156 & 0.0107 & 0.0158 & 0.0102 \\
\hline
\end{tabular}

Table 4.b. Bus Voltages and Phase Angles of the Weak Buses without Facts Devices

\begin{tabular}{l|c|c|c}
\hline BUS NAME & BUS NUMBER & BUS VOLTAGE & ANGLE(DEGREES) \\
\hline NEW HAVEN & 21 & 0.9201 & -32.38 \\
MAKURDI & 22 & 0.9260 & -18.23 \\
DAMATURU & 32 & 0.9283 & -26.13 \\
GOMBE & 33 & 0.9405 & -41.10 \\
MAIDUGURI & 34 & 0.9425 & -12.04 \\
JALINGO & 45 & 0.9354 & -23.18 \\
ERUNKAN & 38 & 0.9314 & -21.32 \\
JOS & 40 & 0.9461 & -13.34 \\
\hline
\end{tabular}


Table 5.0a and 5.0b showed the active and reactive power obtained and the improved bus voltages on incorporation of the FACTS devices.

Table 5.A. Active and Reactive Power Flows at Different Loadings with FACTS Devices

\begin{tabular}{|c|c|c|c|c|c|c|c|c|c|c|c|c|c|}
\hline \multicolumn{2}{|c|}{$\begin{array}{l}\text { CONNECTED } \\
\text { BUS }\end{array}$} & \multicolumn{2}{|c|}{$\begin{array}{l}\text { Active and Reactive } \\
\text { power Flow for } 25 \% \\
\text { Loading in Per Unit } \\
\text { (PU) }\end{array}$} & \multicolumn{2}{|c|}{$\begin{array}{l}\text { Active and Reactive } \\
\text { Power Flow for } \\
50 \% \text { Loading in Per } \\
\text { Unit (PU) }\end{array}$} & \multicolumn{2}{|c|}{$\begin{array}{l}\text { Active and Reactive } \\
\text { Power Flow for } \\
75 \% \text { Loading in Per } \\
\text { Unit (PU) }\end{array}$} & \multicolumn{2}{|c|}{$\begin{array}{l}\text { Active and Reactive } \\
\text { power Flow for } \\
100 \% \text { Loading in } \\
\text { Per Unit (PU) }\end{array}$} & \multicolumn{2}{|c|}{$\begin{array}{l}\text { Active and Reactive } \\
\text { Power Flow for } \\
125 \% \text { Loading in } \\
\text { Per Unit (PU) }\end{array}$} & \multicolumn{2}{|c|}{$\begin{array}{l}\text { Active and Reactive } \\
\text { Power Flow for } \\
150 \% \text { Loading in } \\
\text { Per Unit (PU) }\end{array}$} \\
\hline From & To & $\mathbf{P}$ & $\mathbf{Q}$ & $\mathbf{P}$ & $\mathbf{Q}$ & $\mathbf{P}$ & $\mathbf{Q}$ & $\mathbf{P}$ & $\mathbf{Q}$ & $\mathbf{P}$ & Q & $\begin{array}{l}\mathbf{P} \\
\end{array}$ & $\mathbf{Q}$ \\
\hline 49 & 1 & 0.1777 & 0.0729 & 0.1775 & 0.0725 & 0.1774 & 0.0723 & 0.1772 & 0.0725 & 0.1775 & 0.0729 & 0.1779 & 0.0733 \\
\hline 14 & 6 & 0.0192 & 0.0125 & 0.0199 & 0.0120 & 0.0198 & 0.0123 & 0.0191 & 0.0126 & 0.0195 & 0.0129 & 0.0191 & 0.0121 \\
\hline 2 & 18 & 0.0558 & 0.0385 & 0.0559 & 0.0383 & 0.0560 & 0.0380 & 0.0563 & 0.0385 & 0.0566 & 0.0387 & 0.0569 & 0.0391 \\
\hline 2 & 3 & -0.0039 & 0.0019 & -0.0041 & 0.0017 & -0.0038 & 0.0016 & -0.0041 & 0.0019 & -0.0043 & 0.0021 & -0.0048 & 0.0023 \\
\hline 2 & 4 & 0.0064 & 0.0026 & 0.0065 & 0.0028 & 0.0061 & 0.0027 & 0.0059 & 0.0024 & 0.0060 & 0.0027 & 0.0065 & 0.0029 \\
\hline 16 & 17 & -0.0510 & 0.0569 & -0.0512 & 0.0571 & -0.0509 & 0.0571 & -0.0513 & 0.0573 & -0.0515 & 0.0577 & -0.0519 & 0.0579 \\
\hline 5 & 25 & 0.1618 & 0.2951 & 0.1621 & 0.2996 & 0.1619 & 0.2998 & 0.1616 & 0.2996 & 0.1617 & 0.2999 & 0.1614 & 0.2998 \\
\hline 5 & 6 & 0.0189 & 0.0121 & 0.0187 & 0.0123 & 0.0191 & 0.0124 & 0.0193 & 0.0128 & 0.0194 & 0.0130 & 0.0197 & 0.0133 \\
\hline 5 & 7 & 0.0287 & 0.0188 & 0.0284 & 0.0190 & 0.0285 & 0.0192 & 0.0286 & 0.0190 & 0.0288 & 0.0193 & 0.0289 & 0.0191 \\
\hline 8 & 9 & 0.0997 & 0.0623 & 0.0995 & 0.0621 & 0.0993 & 0.0623 & 0.0992 & 0.0627 & 0.0996 & 0.0629 & 0.0998 & 0.0632 \\
\hline 8 & 31 & 0.0189 & 0.0122 & 0.0188 & 0.0120 & 0.0187 & 0.0124 & 0.0186 & 0.0126 & 0.0189 & 0.0128 & 0.0187 & 0.0134 \\
\hline 10 & 11 & 0.2180 & 0.0137 & 0.2182 & 0.0135 & 0.2186 & 0.0134 & 0.2192 & 0.0132 & 0.2189 & 0.0135 & 0.2193 & 0.0140 \\
\hline 10 & 12 & 0.0241 & 0.0168 & 0.0242 & 0.0172 & 0.0239 & 0.0175 & 0.0238 & 0.0173 & 0.0239 & 0.0176 & 0.0241 & 0.0182 \\
\hline 10 & 13 & 0.0292 & 0.0184 & 0.0290 & 0.0183 & 0.0292 & 0.0186 & 0.0290 & 0.0184 & 0.0292 & 0.0188 & 0.0290 & 0.0189 \\
\hline 16 & 15 & 0.1317 & 0.0167 & 0.1315 & 0.0163 & 0.1314 & 0.0165 & 0.1313 & 0.0167 & 0.1314 & 0.0169 & 0.1315 & 0.0171 \\
\hline 18 & 26 & 0.2459 & 0.1785 & 0.2461 & 0.1784 & 0.2453 & 0.1786 & 0.2452 & 0.1789 & 0.2450 & 0.1791 & 0.2453 & 0.1795 \\
\hline 18 & 3 & 0.0461 & 0.0298 & 0.0457 & 0.0294 & 0.0458 & 0.0292 & 0.0459 & 0.0294 & 0.0461 & 0.0297 & 0.0462 & 0.0299 \\
\hline 18 & 37 & 0.0157 & 0.0119 & 0.0160 & 0.0121 & 0.0155 & 0.0120 & 0.0154 & 0.0121 & 0.0156 & 0.0124 & 0.0158 & 0.0128 \\
\hline 19 & 21 & -0.0028 & 0.0056 & -0.0029 & 0.0053 & -0.0033 & 0.0052 & -0.0032 & 0.0052 & -0.0030 & 0.0055 & -0.0033 & 0.0059 \\
\hline 19 & 22 & 0.0032 & -0.0028 & 0.0033 & -0.0022 & 0.0031 & -0.0021 & 0.0029 & -0.0023 & 0.0032 & -0.0026 & 0.0032 & -0.0024 \\
\hline 23 & 24 & 0.0883 & 0.0548 & 0.0881 & 0.0547 & 0.0879 & 0.0549 & 0.0878 & 0.0550 & 0.0879 & 0.0553 & 0.0875 & 0.0555 \\
\hline 11 & 6 & 0.1611 & -0.0118 & 0.1602 & -0.0120 & 0.1592 & -0.0122 & 0.1620 & -0.0123 & 0.1662 & -0.0125 & 0.1640 & -0.0129 \\
\hline 11 & 15 & 0.0259 & 0.0599 & 0.0258 & 0.0597 & 0.0261 & 0.0599 & 0.0260 & 0.0597 & 0.0261 & 0.0599 & 0.0261 & 0.0602 \\
\hline 11 & 17 & 0.0611 & -0.0552 & 0.0610 & -0.0555 & 0.0613 & -0.0556 & 0.0612 & -0.0555 & 0.0614 & -0.0557 & 0.0616 & -0.0559 \\
\hline 11 & 25 & 0.0106 & 0.0848 & 0.0104 & 0.0851 & 0.0103 & 0.0849 & 0.0105 & 0.0847 & 0.0109 & 0.0849 & 0.0110 & 0.0851 \\
\hline 11 & 26 & 0.2520 & -0.0199 & 0.2504 & -0.0197 & 0.2492 & -0.0199 & 0.2512 & -0.0201 & 0.2522 & -0.0203 & 0.2525 & -0.0208 \\
\hline 11 & 27 & 0.0395 & 0.0303 & 0.0394 & 0.0304 & 0.0390 & 0.0303 & 0.0393 & 0.0301 & 0.0392 & 0.0304 & 0.0394 & 0.0308 \\
\hline 11 & 9 & 0.0924 & -0.0781 & 0.0922 & -0.0783 & 0.0925 & -0.0786 & 0.0927 & -0.0788 & 0.0930 & -0.0791 & 0.0933 & -0.0797 \\
\hline 11 & 28 & 0.0479 & -0.0347 & 0.0482 & -0.0349 & 0.0483 & -0.0347 & 0.0485 & -0.0349 & 0.0487 & -0.0351 & 0.0489 & -0.0355 \\
\hline 27 & 29 & -0.0311 & 0.0196 & -0.0309 & 0.0198 & -0.0310 & 0.0198 & -0.0310 & 0.0199 & -0.0312 & 0.0201 & -0.0314 & 0.0206 \\
\hline 30 & 3 & 0.0287 & 0.0186 & 0.0289 & 0.0189 & 0.0285 & 0.0191 & 0.0286 & 0.0190 & 0.0284 & 0.0193 & 0.0286 & 0.0196 \\
\hline 32 & 33 & 0.0369 & -0.0945 & 0.0371 & -0.0947 & 0.0372 & -0.0949 & 0.0374 & -0.0950 & 0.0376 & -0.0954 & 0.0379 & -0.0959 \\
\hline 32 & 34 & 0.0488 & -0.0851 & 0.0489 & -0.0853 & 0.0491 & -0.0852 & 0.0490 & -0.0853 & 0.0491 & -0.0851 & 0.0493 & -0.0856 \\
\hline 35 & 37 & -0.0185 & 0.0138 & -0.0183 & 0.0135 & -0.0184 & 0.0133 & -0.0187 & 0.0134 & -0.0186 & 0.0136 & -0.0188 & 0.0139 \\
\hline 35 & 36 & -0.0117 & 0.0092 & -0.0115 & 0.0096 & -0.0116 & 0.0094 & -0.0115 & 0.0093 & -0.0117 & 0.0096 & -0.0119 & 0.0094 \\
\hline 9 & 6 & 0.2152 & 0.1552 & 0.2151 & 0.1549 & 0.2150 & 0.1551 & 0.2152 & 0.1554 & 0.2150 & 0.1558 & 0.2153 & 0.1561 \\
\hline 9 & 38 & -0.2609 & 0.0162 & -0.2608 & 0.0164 & -0.2611 & 0.0167 & -0.2612 & 0.0162 & -0.2611 & 0.0165 & -0.2613 & 0.0168 \\
\hline 38 & 6 & -0.2605 & 0.0159 & -0.2602 & 0.0163 & -0.2601 & 0.0161 & -0.2603 & 0.0164 & -0.2602 & 0.0159 & -0.2604 & 0.0162 \\
\hline 39 & 25 & 0.0262 & 0.0405 & 0.0264 & 0.0407 & 0.0260 & 0.0408 & 0.0269 & 0.0406 & 0.0266 & 0.0407 & 0.0268 & 0.0412 \\
\hline 39 & 51 & 0.0261 & -0.0305 & 0.0260 & -0.0307 & 0.0265 & -0.0308 & 0.0266 & -0.0310 & 0.0262 & -0.0308 & 0.0264 & -0.0312 \\
\hline 33 & 40 & 0.0678 & -0.1205 & 0.0677 & -0.1203 & 0.0672 & -0.1205 & 0.0671 & -0.1206 & 0.0673 & -0.1208 & 0.0676 & -0.1209 \\
\hline 33 & 41 & 0.0794 & -0.1006 & 0.0792 & -0.1005 & 0.0799 & -0.1003 & 0.0800 & -0.1005 & 0.0801 & -0.1009 & 0.0803 & -0.1007 \\
\hline 42 & 49 & 0.0117 & -0.0077 & 0.0115 & -0.0078 & 0.0111 & -0.0079 & 0.0112 & -0.0081 & 0.0113 & -0.0082 & 0.0115 & -0.0087 \\
\hline 42 & 13 & 0.0296 & -0.0183 & 0.0295 & -0.0184 & 0.0299 & -0.0186 & 0.0298 & -0.0188 & 0.0300 & -0.0187 & 0.0302 & -0.0189 \\
\hline 42 & 1 & 0.0178 & 0.0113 & 0.0177 & 0.0110 & 0.0177 & 0.0109 & 0.1776 & 0.0110 & 0.1779 & 0.0112 & 0.1777 & 0.0115 \\
\hline 6 & 25 & 0.0183 & -0.0249 & 0.0180 & -0.0251 & 0.0182 & -0.0249 & 0.0180 & -0.0251 & 0.0182 & -0.0253 & 0.0181 & -0.0252 \\
\hline 6 & 28 & 0.0477 & -0.0343 & 0.0478 & -0.0341 & 0.0480 & -0.0338 & 0.0479 & -0.0336 & 0.0476 & -0.0334 & 0.0473 & -0.0338 \\
\hline 6 & 7 & 0.0287 & 0.0187 & 0.0289 & 0.0184 & 0.0287 & 0.0182 & 0.0289 & 0.0184 & 0.0287 & 0.0182 & 0.0283 & 0.0187 \\
\hline 6 & 43 & 0.0367 & -0.0205 & 0.0369 & -0.0203 & 0.0368 & -0.0201 & 0.0366 & -0.0200 & 0.0364 & -0.0201 & 0.0362 & -0.0204 \\
\hline 44 & 3 & 0.0466 & 0.0336 & 0.0464 & 0.0337 & 0.0466 & 0.0336 & 0.0465 & 0.0337 & 0.0464 & 0.0338 & 0.0465 & 0.0339 \\
\hline 3 & 21 & 0.0498 & 0.0318 & 0.0501 & 0.0320 & 0.0503 & 0.0318 & 0.0505 & 0.0316 & 0.0509 & 0.0318 & 0.0506 & 0.0315 \\
\hline 45 & 41 & 0.0881 & -0.1142 & 0.0882 & -0.1144 & 0.0884 & -0.1140 & 0.0882 & -0.1142 & 0.0885 & -0.1144 & 0.0887 & -0.1145 \\
\hline 51 & 25 & 0.2641 & 0.3358 & 0.2642 & 0.3361 & 0.2644 & 0.3359 & 0.2645 & 0.3361 & 0.2647 & 0.3362 & 0.2645 & 0.3367 \\
\hline 47 & 51 & 0.1671 & 0.0607 & 0.1672 & 0.0606 & 0.1673 & 0.0608 & 0.1674 & 0.0609 & 0.1676 & 0.0611 & 0.1676 & 0.0610 \\
\hline 51 & 24 & -0.4849 & 0.0719 & -0.4850 & 0.0722 & -0.4851 & 0.0720 & -0.4853 & 0.0718 & -0.4854 & 0.0716 & -0.4852 & 0.0718 \\
\hline 51 & 1 & 0.1736 & 0.2584 & 0.1735 & 0.2585 & 0.1737 & 0.2583 & 0.1736 & 0.2582 & 0.1737 & 0.2580 & 0.1739 & 0.2584 \\
\hline 40 & 46 & 0.0031 & 0.0057 & 0.0030 & 0.0058 & 0.0031 & 0.0061 & 0.0030 & 0.0063 & 0.0031 & 0.0062 & 0.0033 & 0.0063 \\
\hline 40 & 22 & 0.1273 & -0.0058 & 0.1274 & -0.0053 & 0.1276 & -0.0051 & 0.1274 & -0.0050 & 0.1275 & -0.0051 & 0.1276 & -0.0054 \\
\hline 46 & 1 & 0.1511 & -0.1186 & 0.1510 & -0.1185 & 0.1512 & -0.1184 & 0.1511 & -0.1182 & 0.1513 & -0.1181 & 0.1513 & -0.1184 \\
\hline 46 & 48 & 0.1255 & -0.0889 & 0.1254 & -0.0891 & 0.1252 & -0.0893 & 0.1253 & -0.0890 & 0.1252 & -0.0895 & 0.1250 & -0.0894 \\
\hline 20 & 26 & 0.1349 & 0.0859 & 0.1348 & 0.0861 & 0.1346 & 0.0862 & 0.1348 & 0.0860 & 0.1349 & 0.0863 & 0.1347 & 0.0865 \\
\hline 20 & 21 & -0.0470 & 0.0266 & -0.0472 & 0.0268 & -0.0471 & 0.0267 & -0.0472 & 0.0268 & -0.0474 & 0.0266 & -0.0476 & 0.0268 \\
\hline 50 & 26 & 0.0421 & 0.0687 & 0.0423 & 0.0689 & 0.0422 & 0.0691 & 0.0421 & 0.0693 & 0.0423 & 0.0691 & 0.0422 & 0.0697 \\
\hline 26 & 37 & 0.0159 & 0.0126 & 0.0161 & 0.0128 & 0.0162 & 0.0128 & 0.0161 & 0.0129 & 0.0162 & 0.0132 & 0.0160 & 0.0138 \\
\hline
\end{tabular}

Table 5.b. Bus Voltages and Phase Angles of the Weak Buses without Facts Devices

\begin{tabular}{l|c|c|c}
\hline BUS NAME & BUS NUMBER & BUS VOLTAGE & ANGLE(DEGREES) \\
\hline NEW HAVEN & 21 & 0.9621 & -34.21 \\
MAKURDI & 22 & 0.9804 & -18.21 \\
DAMATURU & 32 & 0.9983 & -29.34 \\
GOMBE & 33 & 0.9751 & -46.23 \\
MAIDUGURI & 34 & 0.9815 & -11.41 \\
JALINGO & 45 & 0.9541 & -33.32 \\
ERUNKAN & 38 & 1.0141 & -27.21 \\
JOS & 40 & 0.9646 & -25.42 \\
\hline
\end{tabular}

Table 6. Total Active and Reactive Power Savings With and Without FACTS Devices at Different Loadings

\begin{tabular}{|c|c|c|c|c|c|c|}
\hline & $\begin{array}{l}\text { Withou } \\
\text { Devices }\end{array}$ & FACTS & With FA & S Devices & Total Sa & \\
\hline $\begin{array}{l}\text { Reactive } \\
\text { power } \\
\text { percentage } \\
\text { loadings }\end{array}$ & $\begin{array}{l}\text { Active } \\
\text { Power } \\
\text { Loss } \\
\text { (pu) }\end{array}$ & $\begin{array}{l}\text { Reactive } \\
\text { Power } \\
\text { Loss(pu) }\end{array}$ & $\begin{array}{l}\text { Active } \\
\text { Power } \\
\text { Loss(pu) }\end{array}$ & $\begin{array}{l}\text { Reactive } \\
\text { Power } \\
\text { Loss(pu) }\end{array}$ & $\begin{array}{l}\text { Total } \\
\text { Active } \\
\text { Power } \\
\text { Savings } \\
\text { (pu) }\end{array}$ & $\begin{array}{l}\text { Total } \\
\text { Reactive } \\
\text { Power } \\
\text { Savings } \\
\text { (pu) }\end{array}$ \\
\hline $25 \%$ & 0.0557 & 0.1259 & 0.0215 & 0.0917 & 0.5355 & 0.0342 \\
\hline $50 \%$ & 0.0573 & 0.1346 & 0.0307 & 0.0995 & 0.0266 & 0.0351 \\
\hline $75 \%$ & 0.0577 & 0.1352 & 0.0328 & 0.1008 & 0.0249 & 0.0344 \\
\hline
\end{tabular}




\begin{tabular}{l|l|l|l|l|l|l}
\hline $100 \%$ & 0.0603 & 0.1361 & 0.0342 & 0.1010 & 0.0261 & 0.0351 \\
$125 \%$ & 0.0621 & 0.1382 & 0.0435 & 0.1017 & 0.0186 & 0.0365 \\
$150 \%$ & 0.0681 & 0.1394 & 0.0514 & 0.1023 & 0.0167 & 0.0371 \\
\hline
\end{tabular}

\section{Discussion}

It is observed that at different percentage loadings ranging from $(25 \%, 50 \%, 75 \%, 100 \%, 125 \%$ and $150 \%)$, different values of active and reactive power flows as well as the weak bus voltages were obtained as shown in table 4.0a and 4.0b. The heavily loaded active and reactive power lines were also obtained. These include: Katampe-Shiroro(49-1), Akangba-Ikejawest(14-6), Aiyede-Oshogbo(5-25), AlaojiOnitsha(18-26), Egbin-ikeja West(9-6), Jebba-Oshogbo(5125), Jebba-Shiroro(51-1), Jos-Makurdi,(40-22), KadunaShiroro(46-1), Kaduna-Kano(46-48), Ajaokuta-Benin(1011), Benin-Ikeja West(11-6), and Benin-Onitsha(11-26) for the active power lines. The weak bus voltages include Damaturu (32), Gombe (33), Maiduguri (34), Makurdi (22), Jalingo (45), Jos (40),Erunkan(38) and New Haven(21). The heavily loaded reactive power lines include: B-KebbiKainji(23-24), Benin-Oshogbo(11-25), Benin-Egbin(11-9), Benin-Sapele(11-15), Damaturu-Gombe(32-33), DamaturuMaiduguri(32-34), Gombe-Yola(33-41), Jalingo-Yola(4541), Ikeja West-Oshogbo(6-25) and Jos-New Haven(40-22).

However, to redistribute the power flows in the entire network and solving the problem of network congestion and bus voltage improvement, FACTS devices were employed at these different loadings (25\%-150\%). Using GA for optimal location of these devices, eight (8) of the thirteen (13) heavily loaded active power lines were installed with UPFC. These include Akangba-Ikejawest (14-6), AlaojiOnitsha(18-26), Jebba-Oshogbo(51-25), Jos-Makurdi (4022), Kaduna-Kano (46-48), Ajaokuta-Benin (10-11), BeninIkeja west (11-6), and Benin-Onitsha (11-26). Also of the eight weak buses in the network as shown in table $4.0 \mathrm{~b}$, six
(6) had UPFC. These include Damaturu (32), Gombe (33), Maiduguri (34), Makurdi (22), Jalingo (45) and Jos (40).GA optimally located six (6) TCSC devices on the ten(10) heavily loaded lines. These include Ikeja West-Oshogbo(625), Damaturu-Maiduguri(32-34), Gombe-Yola(33-41), JosNew Haven(40-22), Benin-Oshogbo(11-25) and B-KebbiKainji(23-24).The result of these is shown in table 5.0a and 5.0b.a summary of the effect of these devices on the heavily loaded power lines resulted to table 6.0.Also a comparison was made with and without FACTS device in the network and the active and reactive power losses were obtained at these different loadings. it was observed that at every percentage loading, there is high saving of both active and reactive power. More so, optimally locating these devices reduced both transmission line losses and congestion, thus improve the overall system stability.

\section{Conclusion}

The effect of reactively loading the Nigeria $330 \mathrm{KV}$ integrated network at different percentages $(25 \%, 50 \%$, $75 \%, 100 \%, 125 \%$ and $150 \%$ ) with and without FACTS devices was studied. The heavily loaded active and reactive power lines as well as the bus voltages were identified. Bus voltages below the statutory allowable limit $( \pm 5 \%$ of $330 \mathrm{KV} ; 313.5 \mathrm{KV}-346.5 \mathrm{KV}$ ) were improved and the heavily loaded lines were regulated using UPFC and TCSC FACTS devices.

Comparison of active and reactive power losses with and without FACTS devices at different loadings was obtained. It was observed that on incorporation of TCSC and UPFC devices into the network optimally using GA, showed reduction in transmission line losses, hence results in savings of both active and reactive power.

\section{References}

1. Omorogiuwa Eseosa, "Efficiency Improvement of the Nigeria $330 \mathrm{KV}$ network using FACTS Device, University of Benin, Benin City 2011.

2. F.D Galiana, K Almeida, "Assessment and control of the Impact of FACTS devices on power system performance", IEEE Transactions on power systems, Vol .II, No 4, pp1931- 1936, November 1996.

3. E.Acha, C.R Fuerte-Esquirel, H .Ambriz-perez and C. AngelesCamacho, FACTS: Modelling and Simulation in power networks. Chictiester, U.K. Wiley, 2004.

4. V.K Sood, HVDC and FACTS Controllers Applications of static converters in power systems. Boston, M.A. Kluver Academic Publisher, 2004.

5. P. Moore and P.Ashmole, "flexible AC Transmission system, "Power Engineering Journal, Vol. 9, No.6, pp 282-286, Dec, 1995.

6. D.J. Gothan and G.T. Heydt, "Power flow control and power flow studies for system with FACTS Devices", IEEE Trans power system, Vol 13. No 1, February 1998.

7. K. Vijayakvmar, R.P Kumudinideri, "A new method for optimal location of FACTS Controllers Using Genetic algorithm”, Journal of theoretical and applied information technology, 2005 - 2007 Jatit.

8. S.Gerbex, R. Cherkaoui and A.J. Germond. "Optimal location of multiple type FACTS Devices in a power system by means of Genetic algorithm. "IEEE Trans power systems. Vol. 16, pp. 537544, August 2001.

9. T.T. Lie and W.Deng, "Optimal flexible AC Transmission systems (FACTS) Devices Allocation," Electrical power and Energy systems, Vol. 19, No 2, pp 125-134, 1994.
10. K.S. Verma, S.N Singh and H.O. Gupta, "Location of unified power flow controller for congestion management, "Electric power systems research, Vol. 58, pp 89-96, 2001.

11. S. Gerbex, R. Cherkaoul and A.J Germond, "Optimal location of multi-type FACTS devices in a power system by means of genetic algorithms IEEE Trans Power Systems, Vol. 16, pp 537-544, August 2001

12. T.T Lie and W. Deng,'Optimal Flexible AC Transmission systems (FACTS) devices allocation,'Electrical power \& Energy system, Vol.19, No.2, pp 125-134, 1997.

13. X. P. Wang, and L. P. Cao, Genetic Algorithms - Theory, Application and Software Realization, Xi'an Jiaotong University, Xi'an, China,1998.

14. F.T. Lie, and W.Deng"optimal flexible AC Transmission systems (FACTS) device allocation", Electrical power and Energy system,Vol.19, no 2,pp125-134,1997.

15. L. Gyugyl, C.D. Shauder and K. K. Sen,"static synchronous series compensator A solid state approach to the series compensation of transmission line," IEEE Transactions o power delivery Vol.12, no. 3, 1997.

16. S. Gerbex, R.Cherkaoui, and A.J.Germund,"optimal location of multi-type FACTS devices in a power system by means of genetic algorithms," IEEE Trans power systems, Vol. 16,pp537544, August 2001.

17. X.P.Wang, and 1.P Cao,"Genetic Algorithms Theory, Application and Software Realization" ,Xi 'an Jiao tong University Xi'an,China, 1998 
Appendix A

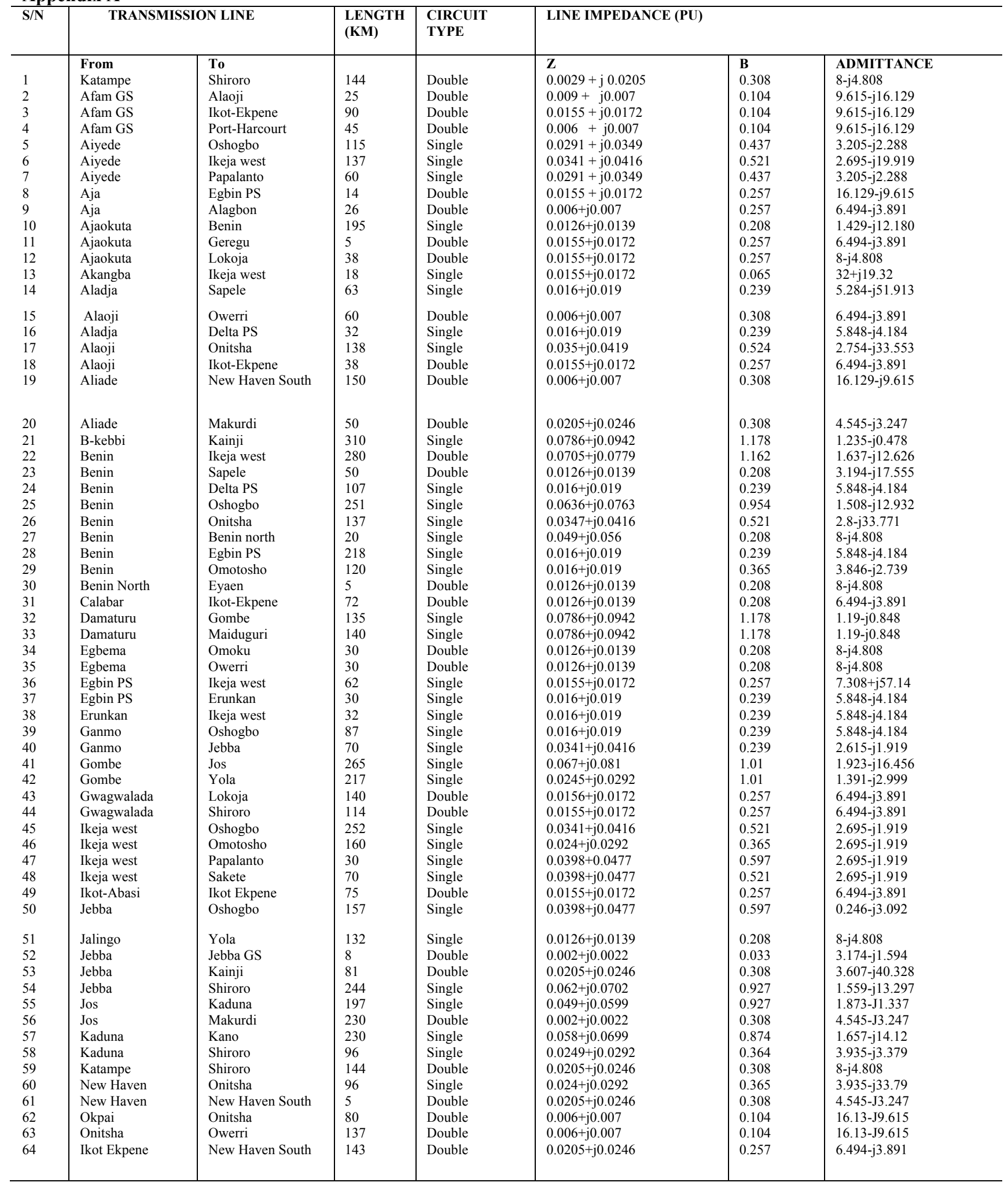

